\title{
Sürekli İntravenöz Prostasiklin Tedavisi Alan Pulmoner Arteriyel Hipertansiyon Hastalarının Hemşirelik Bakımı ve Eğitimi
}

\author{
Dilek Sezgin, (1) Hatice Mert
}

Department of Internal Medicine Nursing, Dokuz Eylül University, İzmir, Turkey

\begin{abstract}
Özet
Pulmoner hipertansiyon pulmoner arter basıncının yükselmesi ile karakterize, sağ kalp yetersizliği ve ölümle sonuçlanabilen bir hastalıktır. Hastaların yaşadıkları semptomlar günlük yaşam aktivitelerini ve yaşam kalitesini önemli derecede kısıtlayabilmektedir. Son yıllarda artış gösteren tedavi seçenekleri hasta sonuçlarını olumlu yönde etkilemektedir. Sürekli intravenöz prostasiklinler ileri evre pulmoner arteriyel hipertansiyon (PAH) tedavisinde tercih edilen tedavi seçeneğidir ve uzun süreli klinik yarar sağlamakta, sağ kalımı iyileştirmektedir. Sürekli intravenöz prostasiklin tedavisi karmaşıktır. Tedavi sürecinin yönetilmesi kritik önem taşır, dozdaki ani artış ve kesintiler ölümcül olabilir. Bu nedenle hemşirelerin hastalara ve bakım verenlerine eğitim vermesi ve izlemesi gerekmektedir. PAH hastaları farklı bir hastalık nedeniyle PAH merkezi dışındaki birimler ve hastanelere yattıklarında bu birimlerde çalışan hemşireler prostasiklin tedavileri ile karşı karşıya kalabilmekte, tedaviyi yönetmede sıkıntı yaşayabilmektedirler. Bu makalenin amacı, sürekli intravenöz prostasiklin tedavisi (epoprostenol) alan hastaların yönetiminde çok önemli rolü olan hemşirelere tedavi sürecinde hastalara sağlayacakları bakım, izlem, eğitim ve danışmanlık hizmetlerine rehber olmaktır.
\end{abstract}

Anahtar sözcükler: Epoprostenol; hemşire; pulmoner arteriyel hipertansiyon; sürekli intravenöz prostasiklin.

\section{Nursing Care and Education of Pulmonary Arterial Hypertension Patients Receiving Continuous Intravenous Prostacyclin Treatment}

\begin{abstract}
Pulmonary hypertension is a disease characterized by elevated pulmonary artery pressure, resulting in right heart failure and death. The symptoms experienced by the patients can significantly effect their daily life activities and quality of life. Treatment options that have increased in recent years have positive effects on patient outcomes. Continuous intravenous prostacyclin is the treatment of choice for advanced pulmonary arterial hypertension (PAH) and provides long-term clinical benefit and improves survival. Continuous intravenous prostacyclin treatment is complex. Management of the treatment process is critical, the sudden increase in dose and interruptions can be fatal. For this reason, nurses should educate and monitor the patients and caregivers. When PAH patients are hospitalized due to a different disease at hospitals and outside PAH centers, nurses working in these units may face prostacyclin treatments and have difficulty in managing the treatment. The aim of this article is to guide to the nurses who have a very important role in the management of patients receiving continuous intravenous prostacyclin treatment (epoprostenol) to provide care, follow-up, training and counseling services to the patients during the treatment process.
\end{abstract}

Keywords: Continuous intravenous prostacyclin; epoprostenol; nurse; pulmonary arterial hypertension.

Cite this article as: Sezgin D, Mert H. Nursing Care and Education of Pulmonary Arterial Hypertension Patients Receiving Continuous Intravenous Prostacyclin Treatment. Turk J Cardiovasc Nurs 2018;9(20):89-95.

İletişim (Correspondence): Dr. Dilek Sezgin. Dokuz Eylül Üniversitesi Hemşirelik Fakültesi, İç Hastalıkları Hemşireliği Anabilim Dalı, İzmir, Turkey Telefon (Phone): +90 2324126977 E-Posta (E-mail): dileksezginn@hotmail.com

Başvuru Tarihi (Submitted Date): 02.11.2018 Kabul Tarihi (Accepted Date): 03.01.2019

oCopyright 2018 by Turkish Society of Cardiology - Available online at www.anatoljcardiol.com 
$\mathrm{P}$ ulmoner arteriyel hipertansiyon (PAH) nadir hastalıklar arasında yer almaktadır ve buna bağlı olarak ileri evredeki PAH hastalarının en etkili tedavi seçeneklerinden biri olan sürekli intravenöz prostasiklin (epoprostenol) tedavisi de nadir uygulanan tedaviler arasında sayılmaktadır. Az rastlanan tedavi olması, yoğun bakım, izlem, eğitim ve danışmanlık gerektirmesi tedavinin karmaşıkığını artırmaktadır. Karmaşık ve az bilinen bir tedavi ile karşı karşıya kalınması durumunda PAH merkezlerinde, klinik ve yoğun bakım ünitelerinde çalışan hemşireler hastaların bakımını yönetmede zorluk yaşayabilmektedir. Bu makalenin amacl, sürekli intravenöz prostasiklin tedavisi (epoprostenol) alan hastaların yönetiminde hemşirelerin tedaviye yönelik bakım, izlem, eğitim ve danışmanlık süreçlerine rehber olmaktır.

\section{Pulmoner Hipertansiyon Tanımı}

Pulmoner hipertansiyon(PH), pulmoner arter basıncının yükselmesi sonucu sağ ventrikül yetersizliği ile karakterize, günlük yaşam aktivitelerini kısıtlayabilen semptomlarla seyreden, kronik, ilerleyici bir hastalıktır. ${ }^{[1]} \mathrm{PH}$, sağ kalp kateterizasyonu (SKK) ile ölçülen ortalama pulmoner arter basıncının (PABo) dinlenme halinde $25 \mathrm{mmHg}$ veya daha yüksek bulunması olarak tanımlanmaktadır. Pulmoner arter basıncındaki yükselme kalp-damar ve solunum sisteminde fizyopatolojik bozukluk oluşturmakta, bu durum hastaların yaşam kalitelerini olumsuz yönde etkilemektedir. ${ }^{[2,3]}$

\section{Pulmoner Hipertansiyon Etiyolojisi}

$\mathrm{PH}$, kırka yakın hastalığın seyrinde gözlenmektedir. PH benzer klinik tablolara, patolojik bulgulara, hemodinamik özelliklere ve tedavi stratejilerine göre sınıflandırılmıştır. PH bu özelliklere göre beş gruba ayrılmıştır. PAH (Pulmoner Arteriyel Hipertansiyon) PH sınıflamasının alt gruplarından Grup 1 olarak tanımlanmıştır. ${ }^{[4]}$ Sürekli intravenöz prostasiklin (epoprostenol) tedavisi Grup 1 PAH hastalarının tedavisinde yer aldığı için makalede PAH ifadesi kullanılmıştır.

PAH İdiyopatik, kalıtsal (BMPR2 mutasyonu ve diğer mutasyonlar), ilaçlara ve toksinlere bağlı, diğer hastalıklarla ilişkili (bağ dokusu hastalığı, insan immün yetmezlik virüsü [HIV] enfeksiyonu, portal hipertansiyon), doğuştan kalp hastalığı (Eisenmenger sendromu, süregelen sistemik-pulmoner şantlarla ilişkili PAH, küçük/rastlantısal defektlerle birlikte olan PAH, defekt onarımı sonrasında PAH) ve şistomiyazis ile ilişkili olarak gelişebilmektedir. ${ }^{[2]}$

\section{Pulmoner Arteriyel Hipertansiyon Epidemiyolojisi}

Literatürde PAH epidemiyolojisine ilişsin bilgiler kısıtıdır. PAH ve idiyopatik PAH (IPAH) prevalansının sırasıyla milyonda 15 ve 5.9 yetişkin olgu olduğu, PAH insidansının yetişkin nüfusta yıllık milyonda 2.4 vaka olduğu tahmin edilmektedir. ${ }^{[2,5,6]}$

\section{Pulmoner Arteriyel Hipertansiyon Fizyopatolojisi}

PAH fizyopatolojisinde artmış pulmoner vasküler dirence (PVR) yol açan üç önemli faktör rol oynamaktadır. Bunlar vazokonstriksiyon, küçük arterlerin düz kas hipertrofisi ve in situ trombozudur. Kronik aşırı vazokonstriksiyon, endotel disfonksiyonuna, nitrik oksit (NO) ve prostasiklinin yetersiz üretimi ve aşırı endotelin-1 salınımına yol açmaktadır. ${ }^{[3,7,8,9]}$

Pulmoner vasküler yataktaki patolojik değişiklikler sonucunda günlük aktivite veya egzersiz için gerekli olan kardiyak output karşılanayamayacak duruma gelebilmektedir. Bu durum, pulmoner vasküler yataktaki basıncın artmasına neden olmaktadır. Zamanla, sağ ventrikül hipertrofisi ve dilatasyonu ortaya çıkmakta ve sağ ventrikülün kalp debisini koruması zorlaşmaktadır. Buna ek olarak, bu patolojik değişiklikler, ventilasyon-perfüzyon oranını değiştirebilmekte ve arteriyel hipoksemiye katkıda bulunmaktadır. Düşük kalp debisi ve arteriyel hipokseminin sonucu olarak hastalarda sağ kalp yetersizliği semptomları gelişmektedir. ${ }^{[10,11,12]}$

\section{Pulmoner Arteriyel Hipertansiyon Semptomları}

PAH semptomları spesifik değildir ve hastalarda temel olarak progresif sağ ventrikül disfonksiyonu semptomları gözlenmektedir. Başlangıçta semptomlar hareketle birlikte ortaya çıkmaktadır. Hastalarda sık gözlenen semptomlar nefes darlığı, halsizlik, yorgunluk, angına, senkop, batın distansiyonu ve ödemdir. Kuru öksürük ve egzersize bağlı bulantı ve kusma daha nadir gözlenmektedir. Bazı hastalarda klinik tablo PH' nin mekanik komplikasyonları ve pulmoner vasküler yataktaki anormal kan akımı ile ilişkili olmaktadır. Bunlar hipertrofiye bronşiyal arterlerin rüptürü ile ilişkili hemoptizi, pulmoner arteriyel dilatasyona atfedilebilen semptomlardan laringeal sinir sıkışması/basısı sonucu ses kısıklığı, büyük hava yolu kompresyonunun neden olduğu hırıltıdır. Pulmoner arterin önemli ölçüde genişlemesi kardiyak tamponad belirti ve semptomlarına yol açan disseksiyon veya rüptürle sonuçlanabilmektedir. Illeri evre hastalarda jügüler ven basınç artışı, hepatomegali, asit, periferik ödem ve soğuk ekstremite bulguları görülmektedir. ${ }^{[2,7,12,13]}$

\section{Pulmoner Arteriyel Hipertansiyon Tedavisi}

PAH tedavisinde son yıllarda giderek artan bir gelişme sağlanmakta, hastaların yaşadıkları semptomlar önemli ölçüde önlenebilmektedir. PAH tedavisi genel önlemler (fiziksel aktivite ve gözetim altında rehabilitasyon, gebelik, doğum kontrolü ve menopoz sonrası hormon tedavisi, elektif cerrahi, enfeksiyondan korunma, psikososyal destek, tedavilere uyum, genetik danışmanlık ve seyahat) destek tedavi (oral antikoagülanlar, diüretikler, $\mathrm{O} 2$, digoksin), ve PAH'a özgül 
tedavilerden (kalsiyum kanal blokerleri, endotelin reseptör antagonistleri, fosfodiesteraz tip 5 inhibitörleri ve guanilat siklaz uyarıcıları, prostasiklinler) oluşmaktadır. ${ }^{[2]}$

\section{Prostasiklinler}

PAH tedavisinde oral yolla verilen tedavi hafif-orta evredeki PAH hastalarının tedavisinde etkilidir. Sürekli intravenöz prostasiklinler ileri evre PAH tedavisi için en etkili tedavidir. Yapılan çalışmalarda sürekli intravenöz epoprostenol tedavisi alan hastaların egzersiz kapasitelerinde artma, semptomlar ve hemodinamik parametrelerde iyileşme, yaşam kalitesinde ve sağ kalımda artma olduğu belirtilmiştir. ${ }^{[14-18]}$

\section{Sürekli İntravenöz Prostasiklinlerin Etki Mekanizması}

Prostasiklinler güçlü vazodilatörlerdir ve antitrombotik ve antiproliferatif özelliklere sahiptir; siklik adenozin monofosfat konsantrasyonlarının arttırımasıyla pulmoner yatakta vazodilatasyona ve trombosit agregasyonunun inhibisyonuna neden olmaktadırlar. Pulmoner arterlerin vazodila- tasyonu, sağ ventrikülün iş yükünü azaltmakta, akciğerlere gelen kan akışını artırmakta ve pulmoner arter basıncını düşürmektedir; bunların hepsi PAH semptomlarının ve egzersiz kapasitesinin iyileşmesine neden olmaktadır. $[2,19,20,21]$

\section{Sürekli İntravenöz Prostasiklin Tedavisinin Hazırlanması}

Sürekli intravenöz prostasiklin (Epoprostenol) tedavisi yarılanma ömrünün kısa olması nedeniyle sürekli alınması gereken bir tedavi şeklidir. Tedavi kalıcı olarak yerleştirilmiş santral kateter aracılığı ile verilir. Epoprostenol tedavisinin hazırlanması Şekil 1'de gösterilmiştir.

İlaç tedavisi günlük olarak ilaç kasetlerine hazırlanmalıdır. Epoprostenol flakonu 5 cc serum fizyolojik solüsyonu ile seyreltilir, 95 cc serum fizyolojik eklenerek ilaç kasetinde toplam $100 \mathrm{cc}$ sıvı olması sağlanır. Tedavinin ilerleyen zamanlarında bir günlük doz hazırlanması için 2 ya da 3 flakon ilaca gereksinim olabilir. Bu durumlarda her bir flakon 5 cc olarak hesaplanıp kalan miktar serum fizyolojik ile tamamlanmalıdır. Bu işlemler gerçekleştirildiğinde ilaç kaseti

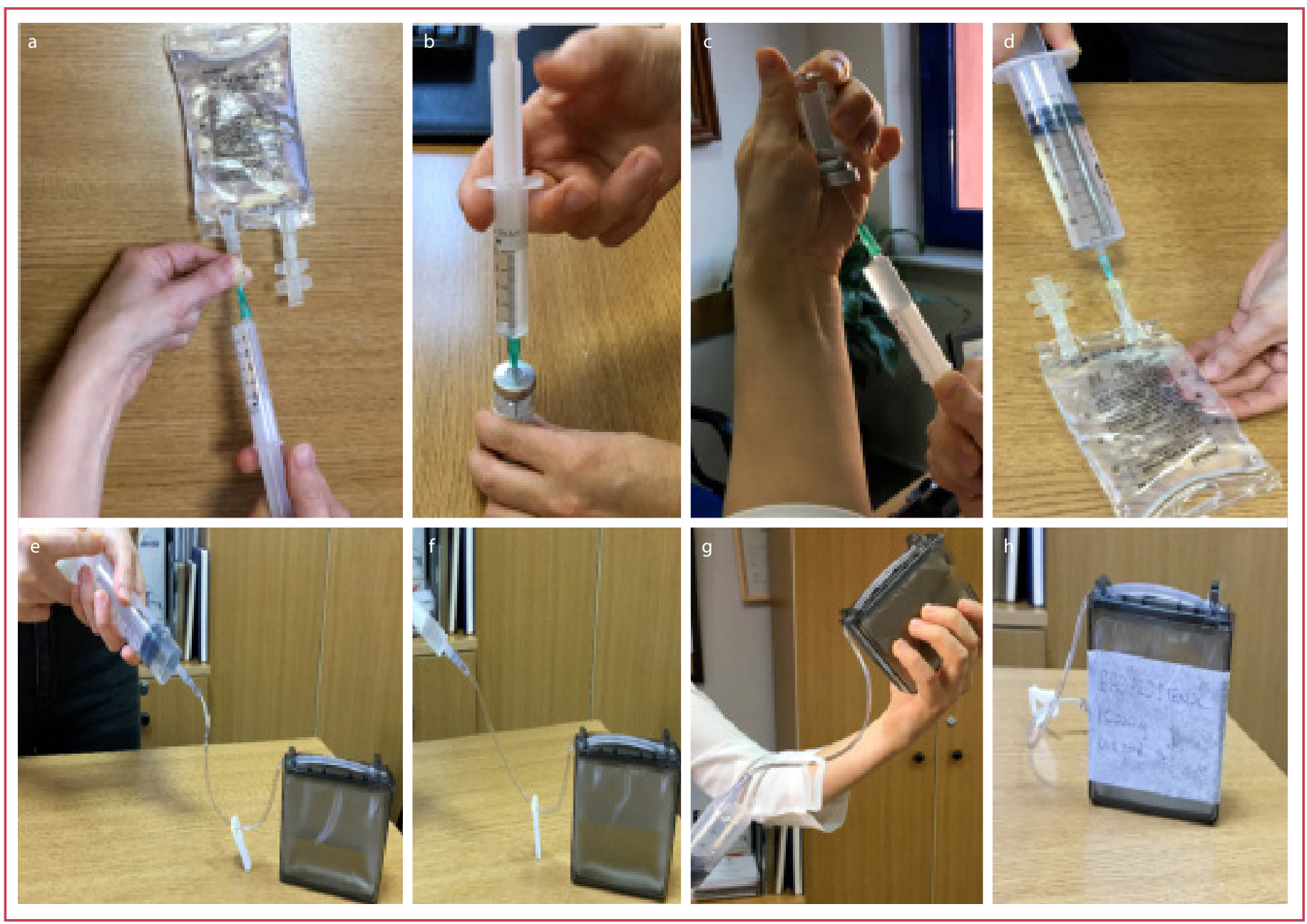

Şekil 1. Epoprostenol tedavisinin hazırlanması. 
hazırlanmış olmaktadır (Şekil 1). Epoprostenol konsantrasyonlarının hazırlanmasına ilişkin bilgiler Tablo 1'de yer almaktadır. İlaç seyreltildikten sonra ilaç kasetinin havası çıkarılmalıdır (Şekil 1). ${ }^{[11,13,22]}$

Epoprostenol flakonu ilaç kasetine hazırlandıktan sonra infüzyon pompasına bağlantı işlemlerine geçilmelidir (Şekil 2). İlaç kasetinin değiştirilmesi için eski kasetin infüzyon pompasından ayrılması ve vakit geçirmeden yenisiyle değiştirilmesi gerekmektedir (ilacın yarı ömrü 2-3 dakika). Bu nedenle ilaç hazırlandıktan sonra kasetlerin değiştirilmesi işlemine geçilmesi gerekir. Ilaç kasetleri hazırlandıktan sonra oda ısısında 24 saat termostabil, buzdolabında 7 gün termostabildir. Bu nedenle hastalar 7 günlük tedavilerini hazırlayarak buzdolabında saklayabilirler. Hastalar ilaç kasetlerini hazırlama tarih ve saatini, konsantrasyon oranını kasetin üzerine belirtmelidir. ${ }^{[11,13,23-25]}$

Eski ilaç kasetinin infüzyon pompasından çıkarılabilmesi ve yeni kasetin infüzyon pompasına yerleştirilebilmesi için infüzyon pompasına ait bir anahtar bulunmaktadır. Bu anahtar acil durumlar söz konusu olabileceği için hastanın yanında bulunmalıdır (Şekil 2).

İlaç kasetinin santral venöz kateterle bağlantısının sağlanabilmesi için infüzyon seti kullanılmaktadır. Set yerleştirildikten sonra infüzyon pompasının doz ayarları yapılmalı ve infüzyon setinin havası çıkarılmalıdır (Şekil 2).

Epoprostenol tedavisi infüzyon hızının belirlenmesinde

\begin{tabular}{|c|c|c|c|c|c|c|}
\hline 3.000 & $0.5 \mathrm{mg}$ & 1 & 5 & 3 & 97 & 100 \\
\hline 5.000 & $0.5 \mathrm{mg}$ & 1 & 5 & 5 & 95 & 100 \\
\hline 30.000 & $1.5 \mathrm{mg}$ & 2 & $10(2 \times 5)$ & 10 & 90 & 100 \\
\hline 45.000 & $1.5 \mathrm{mg}$ & 3 & $15(3 \times 5)$ & 15 & 85 & 100 \\
\hline 60.000 & $1.5 \mathrm{mg}$ & 4 & $20(4 \times 5)$ & 20 & 80 & 100 \\
\hline 75.000 & $1.5 \mathrm{mg}$ & 5 & $25(5 \times 5)$ & 25 & 75 & 100 \\
\hline 90.000 & $1.5 \mathrm{mg}$ & 6 & $30(6 \times 5)$ & 30 & 70 & 100 \\
\hline
\end{tabular}

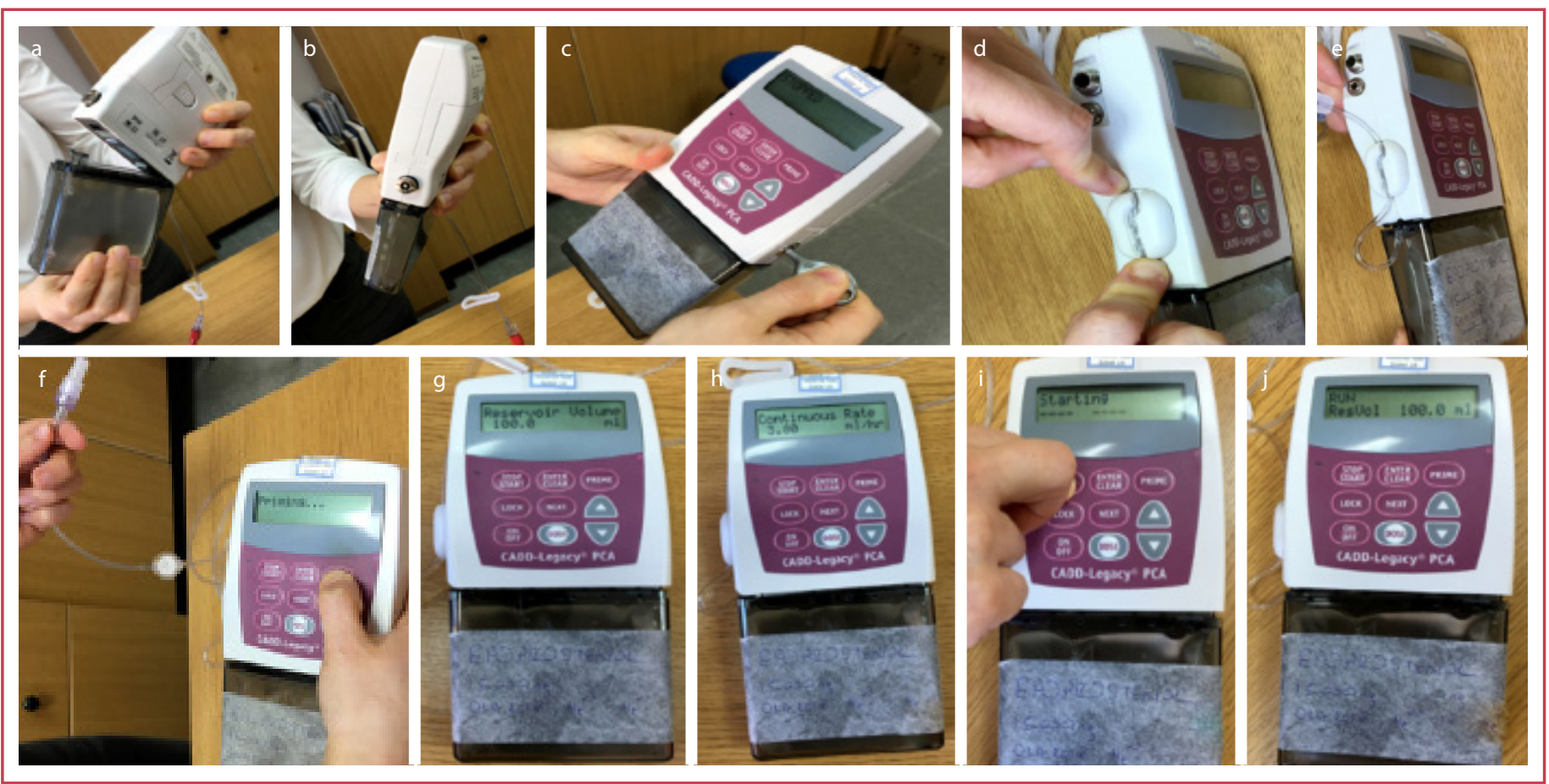

Şekil 2. İlaç kasetinin infüzyon pompası ile bağlantısının sağlanması. 


\begin{tabular}{|c|c|}
\hline \multirow[t]{2}{*}{ İnfüzyon hızı (ml/saat): } & Doz (ng/kg/dak) X Vücut ağırlığı (kg)X60 \\
\hline & Solüsyon konsantrasyonu (ng/ml) \\
\hline \multicolumn{2}{|c|}{$\begin{array}{l}\text { Örnek: Vücut ağırlığı } 70 \mathrm{~kg} \text { olan hastaya } 5.000 \text { konsantrasyonda } \\
\text { hazırlanmış epoprostenol tedavisini } 2 \mathrm{ng} / \mathrm{kg} / \text { dak dozunda } \\
\text { uygulayabilmek için: }\end{array}$} \\
\hline \multirow[t]{2}{*}{ İnfüzyon hızı (ml/saat): } & $2 \mathrm{ng} / \mathrm{kg} / \mathrm{dak} \times 70 \mathrm{~kg} \times 60$ \\
\hline & $5000(\mathrm{ng} / \mathrm{ml})$ \\
\hline \multicolumn{2}{|c|}{ Formüle göre sonuç 1.68'dir. } \\
\hline \multicolumn{2}{|c|}{$\begin{array}{l}\text { *Epoprostenol tedavisi için kullanılan infüzyon pompaları ondalık } \\
\text { sayılarla ilaç ayarlaması yapabildiği için bu ilaç dozu } 1.7 \text { cc olarak } \\
\text { ayarlanabilir. }\end{array}$} \\
\hline
\end{tabular}

hastanın kilosu, verilecek doz miktarı ve hazırlanan ilacın konsantrasyonu önem taşımaktadır. İnfüzyon hızının hesaplanmasına ilişkin formül Tablo 2'de yer almaktadır.

\section{Epoprostenol Tedavisine Yönelik Hemşirelik Bakımı}

Epoprostenol tedavisini hastaların evde uygulaması ve yönetmesi beklenmektedir. Hasta ve yakınları evde ilaç tedavisinin yönetilmesi konusunda sorumluluk alacakları için tedavinin sürdürülmesinde yaşanacak problemler yaşamsal sorunlara yol açabilir. Tedavi uygulanmaya başlamadan önce hastanın ve tedavi uygulamasında sorumluluk alacak yakınlarının fiziksel, bilişsel ve emosyonel yeterlilikleri değerlendirilmelidir. Bu nedenle ilaç tedavisinin hazırlanması ve dikkat edilmesi gerekenler mutlaka hemşire tarafından hasta ve yakınlarına anlatılmalı, uygulama yaptırılarak yanIışları düzeltilmelidir. İlaç tedavisinin evde güvenli şekilde hazırlanacağından emin olmadan hastanın taburculuğu planlanmamalıdır. $[8,11,13,23,27-29]$

Epoprostenol tedavisi ciddi yan etkileri olabilmesi nedeniyle hastanede başlanmalıdır ve hasta için etkin doza ulaşıncaya kadar hastanede izlenmelidir. Epoprostenol dozunun düzenlenmesinde $\mathrm{PAH}$ merkezlerinde farklı yaklaşımlar olabilmekle birlikte intravenöz epoprostenol infüzyonu 2 $\mathrm{ng} / \mathrm{kg} /$ dakika ile başlatılır. Doz kademeli olarak artırılır ve semptomlarda iyileşme görülen doz belirlenir. ${ }^{[23-25,27,30]}$

Epoprostenol tedavisi, uygulama öncesinde veya sırasında diğer parenteral ilaçlar veya solüsyonlarla karıştırılmamalıdır. Işıktan korunmalıdır. İlaç hazırlama sırasında steril çalışmak önemlidir. İlaç hazırlığı yapılan alan alkol/klorheksidin solüsyonu ile temizlenmelidir. İlaç hazırlığına başlamadan önce ilaç hazırlayan kişiler mutlaka ellerini yıkamalıdı. Illaç tedavisi hazırlamada kullanılan malzemelerin kontaminasyonu önlenmelidir. Kontamine malzemelerle infüzyonun yapılması kateter enfeksiyonu ya da sepsise neden olabilir. ${ }^{[8,11,13,22]}$
Hasta yan etkiler açısından izlenmelidir. Epoprostenol tedavisi başlangıcında kan basıncı, nabız, solunum hızı, oksijen saturasyonu ilk bir saatte 15 dakikada bir, 2 . ve 3. saatte her 30 dakikada bir, hasta stabil duruma gelinceye kadar saatte bir izlenmelidir. Hastada uygun titrasyona ulaşıldıktan sonra her 4 saatte bir izlenmelidir. ${ }^{[28]}$

Tedavinin başlangııında çene ağrısı, baş ağrısı, diyare, sistemik hipotansiyon, mide bulantısı, kusma, flushing ve fotosensitivite gibi yan etkiler görülebilmektedir. Hasta için uygun doza ulaşılınca bu yan etkiler genellikle gerilemektedir. Hastalar yan etkiler konusunda bilgilendirilmelidir. ${ }^{[23-25,27,30]}$

Tedavi sürecinde ağrı (baş ve çene ağrısı) değerlendirilmeli, ağrının azaltılabilmesi için nonfarmakolojik yöntemler (masaj, relaksasyon teknikleri, sıcak/soğuk uygulamalar) kullanılmalıdır. Çene ağrısı beslenmeyi etkileyebileceği için yemek öncesi sakız çiğneme ya da sert şeker yeme önerilmektedir. Besinleri yavaş çiğnemesi konusunda bilgilendirilmelidir. Şiddetli ağrılarda hekim önerisi doğrultusunda analjezik tedavi uygulanarak hastanın konforu sağlanmalıdır. Tedavi başlangıcında baş dönmesi ve hipotansiyon görülebilmektedir. Bu nedenle hastanın kan basıncı yakından izlenmeli ve hastanın ani hareketlerden kaçınması sağlanmalıdır. Hasta yataktan kalkarken yalnız bırakılmamalı, güvenliği sağlanmalıdır. Bulantı, kusma vagal etki oluşturması nedeniyle önlenmelidir. Hastalara küçük porsiyonlarda besinlerin tüketimi, bulantıyı artırabilecek besinlerden kaçınması gerektiği anlatılmalıdır. Hekim önerisi doğrultusunda antiemetik ilaçlar uygulanabilir. Diyarenin önlenebilmesi için beslenme programına probiyotik içerikli besinler eklenebilir. Gluten içeren besinlerden uzak kalması önerilebilir. Hekim önerisi doğrultusunda diyarenin önlenmesine yönelik farmakolojik tedavi uygulanmalıdır. Flushing genellikle yüzde kızarıklık olarak görülmektedir. Hasta yüzde sıcaklık artışı olduğunu ifade edebilir. Sıcaklık hissinin azaltılabilmesi için soğuk kompres uygulanabilir. Anksiyete azaltılmaya çalışılmalıdır. Belirtinin tedavi başlangıcında yaşanabildiği, geçici bir durum olduğu hastaya anlatılmalıdır. ${ }^{[31]}$

Epoprostenol tedavisi sürecinde santral katetere ilişkin komplikasyonlar yaşanabilmektedir. Bu komplikasyonlar, lokal kateter enfeksiyonları, kateter yolu enfeksiyonları, bakteriyemi veya sepsis, tromboz, kateter hattı bozukluğu (delik veya sızıntı), tıkanıklık, kateter hattı yer değiştirmesi, kateterin çıkması olabilmektedir. Bu nedenle kateter bölgesinin izlem ve bakımının sağlanması büyük önem taşımaktadır. ${ }^{[11,13,23,30]}$

Kateter giriş yeri ve kateter hattı boyunca şişlik, kızarıklık, ısı artışı, sızıntı, hassasiyet, kaşıntı, cilt reaksiyonu, ağrı olup olmadığı günlük olarak değerlendirilmelidir. Kullanı- 
lan bariyer malzemenin özelliklerine göre düzenli kateter pansumanı yapılmalıdır. Şeffaf pansuman örtülerinin ıslanma, açılma, giriş bölgesinde kanama, akıntı olmadıkça yedi günde bir değiştirilmesi önerilmektedir. Gaz bezi ile yapılan pansumanların 1-2 günde bir değiştirilmesi gerekmektedir. Şeffaf örtü kullanımına ilişkin kontraendikasyon yoksa kateter bölgesinin gözlemi daha net yapılabileceği ve kateter bölgesinin sık sık açılması önleneceği için şeffaf örtülerin kullanımı önerilmektedir. ${ }^{[11,13,23,32-35]}$

Hastalar ve bakım verenlerine kateter bakımına ilişkin eğitimi alanında uzman hemşireler vermelidir. Pansuman steril olarak yapılmalı, steril eldiven ve maske kullanımı önerilmektedir. Pansuman yapılırken $\% 5$ klorheksidin solüsyonu kullanılmalıdır. Bu nedenle kateter bakımı yapacak kişilerin hasta taburcu edilmeden önce steril eldiven giyme becerisi kazanmış olması gerekmektedir. Hasta taburculuğundan önce kateter bakımını üstlenen kişinin hemşire gözetiminde kateter pansumanını eksiksiz yapabiliyor durumuna gelinceye kadar tekrar yapması sağlanmalıdır. Pansumanın tarihi, kateter uzunluğunu evde kayıt tutmaları gerektiği anlatılmalıdır. Ev ortamında hastanın bakımından sorumlu kişiler değişecekse bu kişilerin de eğitiminin tamamlanması önemlidir. Hasta ve bakım verenlerin eğitimi sırasında kateterin suyla temas etmemesi gerektiği, hastalara yüzme önerilmediği belirtilmelidir. Hasta ve bakım verenlerin kateter pansumanının önemi konusunda yeterli bilgiye sahip olmaları yaşamsal önem taşımaktadır. [11, 13, 23, 32-35]

Epoprostenol tedavisi sırasında infüzyon setinde hava olması, infüzyon hattında tıkanıklık olması, pilin azalması, dozun azalması durumlarında infüzyon pompası alarm vermektedir. Cihazlarda yaşanabilecek sorunlar nedeni ile hastalara yedek infüzyon pompası sağlanmalıdır ve cihaz arızalarında hastanın infüzyonunun kesintiye uğraması önlenmelidir. Hastalara ve yakınlarına alarm durumunda yapacakları işlemler ayrıntılı olarak açıklanmalıdır. Hastalara, evden dışarı çıkmaları durumunda mutlaka yedek infüzyon pompası, yedek pil, infüzyon pompası anahtarı ve ilaç hazırlanması için gerekli malzemeleri (yedek ilaç, serum fizyolojik, enjektör) yanında bulundurması konusunda bilgi verilmeli, yedek malzemelerin temini için geçirilecek sürenin yaşamsal değeri vurgulanmalıdır. Hastaların sorunu çözemedikleri durumlarda danışmanlık alabilecekleri telefon numarası sağlanmalıdır. $[13,23,28,36,37]$

Epoprostenol tedavisi alan hastaların ve yakınlarının fiziksel, sosyal, emosyonel açıdan yaşamları etkilenebilmektedir. Bu nedenle hasta ve yakınları uzun dönem tedavi sürecinde tedaviye uyum sorunları yaşayabilmektedir. Hemşirelerin hasta ve yakınlarını düzenli olarak izlemeleri, psikososyal destek sağlamaları büyük önem taşımaktadır. ${ }^{[11,13,23,27,37]}$

\section{Sonuç}

PAH nadir görülen hastalıklar arasında, kompleks tedavi ve bakım gerektiren bir hastalıktır. Bu hastalığın ve epoprostenol tedavisinin yönetiminin sağlanmasında hemşirenin önemli rolü bulunmaktadır. Bu makale tedavinin etkin biçimde uygulanmasında, hasta ve bakım verenlerin eğitiminde hemşirelere yol gösterici olacaktır.

Hakem Değerlendirmesi: Dış bağımsız.

Çıkar Çatışması: Yazarlar arasında herhangi bir çıkar çatışması bulunmamaktadır.

Yazarlık Katkıları: Konsept: D.S.; Dizayn: D.S., H.M.; Veri Toplama veya Işleme: D.S., H.M.; Analiz veya Yorumlama: D.S., H.M.; Literatür Arama: D.S.; Yazan: D.S., H.M.

\section{Kaynaklar}

1. Mc Donough A, Matura LA, Carroll DL. Symptom Experience of Pulmonary Arterial Hypertension Patients. Clin Nurs Res 2011;20:120-34. [CrossRef]

2. Galiè N, Humbert $M$, Vachiery JL, Gibbs $S$, Lang I, Torbicki A, et al. 2015 ESC/ERS Guidelines for the Diagnosis and Treatment of Pulmonary Hypertension: The Joint Task Force for the Diagnosis and Treatment of Pulmonary Hypertension of the European Society of Cardiology (ESC) and the European Respiratory Society (ERS): Endorsed by: Association for European Paediatric and Congenital Cardiology (AEPC), International Society for Heart and Lung Transplantation (ISHLT). Eur Heart J 2016;37:67-119. [CrossRef]

3. Hoeper MM, Bogaard HJ, Condliffe R, Frantz R, Khanna D, Kurzyna $M$, et al. Definitions and Diagnosis of Pulmonary Hypertension. J Am Coll Cardiol 2013;62(Suppl):42-50.

Küçükoğlu MS, Sinan ÜY. 2015 ESC Pulmoner Hipertansiyon Kılavuzu'nda Yeni Anlayışlar. Turk Kardiyol Dern Ars 2016; 44:4-8.

5. McGoon MD, Benza RL, Escribano-Subias $P$, Jiang $X$, Miller DP, Peacock AJ, et al. Pulmonary Arterial Hypertension: Epidemiology and Registries. J Am Coll Cardiol 2013;62(Suppl):51-9.

6. Simonneau G, Gatzoulis MA, Adatia I, Celermajer D, Denton C, Ghofrani A, et al. Updated Clinical Classification of Pulmonary Hypertension. J Am Coll Cardiol 2013;62:34-41. [CrossRef]

7. Galiè N, Hoeper MM, Humbert M, Torbicki A, Vachiery JL, Barbera JA, et al. Guidelines for the Diagnosis and Treatment of Pulmonary Hypertension: the Task Force for the Diagnosis and Treatment of Pulmonary Hypertension of the European Society of Cardiology (ESC) and the European Respiratory Society (ERS), endorsed by the International Society of Heart and Lung Transplantation (ISHLT). Eur Heart J 2009;30:2493-537.

8. Waxman $A B$, Zamanian RT. Pulmonary Arterial Hypertension: New Insights into the Optimal Role of Current and Emerging Prostacyclin Therapies. Am J Cardiol 2013;111(5 suppl):1-16.

9. Trammell AW, Hemnes AR. Pathogenesis of pulmonary arterial hypertension. In: Klinger JR, Frantz RP editor. Diagnosis and 
management of pulmonary hypertension. London: Humana Press; 2015. p. 37-65. [CrossRef]

10. Bacon J, Madden B. The pathophysiology, presentation and diagnostic investigation of pulmonary hypertension. In: Madden B editor. Treatment of pulmonary hypertension. Switzerland: Springer International Publishing; 2015. p.1-35. [CrossRef]

11. Archer-Chicko $C$. Nursing care of patients with pulmonary arterial hypertension. In: Yuan JXJ, editor. Textbook of Pulmonary Vascular Disease. Boston: Springer Nature; 2010. p.1531-58.

12. Tartavoulle TM. Evaluation and Management of the Adult Patient with Pulmonary Hypertension. The Journal for Nurse Practitioners - JNP, 2011;7:409-16. [CrossRef]

13. Archer-Chicko C, Housten-Harris T, Palevsky HI. Practical nursing issues in the outpatient management of pulmonary vascular disease. In: Mandel J, Taichman D, editor. Pulmonary Vascular Disease. Elsevier; 2006. p.314-29. [CrossRef]

14. Sitbon $O$, Humbert $M$, Nunes $H$, Parent F, Garcia G, Hervé $P$, et al. Long-Term Intravenous Epoprostenol Infusion in Primary Pulmonary Hypertension: Prognostic Factors and Survival. J Am Coll Cardiol 2002;40:780-8. [CrossRef]

15. Jiménez MP, Subías $P E$, Tello de Meneses $R$, Gómez-Sánchez MA, Jiménez D, González-Gallarza RD, et al. Ten Years' Experience in Continuous Intravenous Epoprostenol Therapy in Severe Pulmonary Arterial Hypertension. Rev Esp Cardiol 2003;56:230-5.

16. Bergot E, Sitbon O, Cottin V, Prevot G, Canuel M, Bourdin A, et al. Current Epoprostenol Use in Patients with Severe Idiopathic, Heritable or Anorexigen-Associated Pulmonary Arterial Hypertension: Data from the French Pulmonary Hypertension Registry. Int J Cardiol 2014;172:561-7. [CrossRef]

17. Frantz RP, Schilz RJ, Chakinala MM, Badesch DB, Frost AE, McLaughlin VV, et al. Hospitalization and Survival in Patients Using Epoprostenol for Injection in the PROSPECT Observational Study. Chest 2015;147:484-94. [CrossRef]

18. Rousseau J, Chı J. Continuous Infusion of Epoprostenol as Salvage Therapy for Severe Pulmonary Arterial Hypertension. Clin Res Prac 2018;28:1,eP1623.

19. Kingman MS, Lombardi S. Management of the Patient with Pulmonary Arterial Hypertension Receiving Intravenous Prostacyclin, an Expert Nurse Practical Guide. The Art and Science of Infusion Nursing 2014;7:442-51. [CrossRef]

20. Wapner J, Matura LA. An Update on Pulmonary Arterial Hypertension. The Journal for Nurse Practitioners 2015;11:551-9.

21. Sitbon O, Vonk Noordegraaf A. Epoprostenol and Pulmonary Arterial Hypertension: 20 Years of Clinical Experience. Eur Respir Rev 2017;26:160055. [CrossRef]

22. Safdar Z. Treatment of Pulmonary Arterial Hypertension: The Role of Prostacyclin and Prostaglandin Analogs. Respiratory Medicine 2011;105:818-27. [CrossRef]

23. Farber HW, Gin-Sing W. Practical Considerations for Therapies Targeting the Prostacyclin Pathway. Eur Respir Rev
2016;25:418-30. [CrossRef]

24. Stewart T. Pulmonary Arterial Hypertension: A Focus on Infused Prostacyclins. The Art and Science of Infusion Nursing 2016;9:15-26. [CrossRef]

25. Mubarak KK. A Review of Prostaglandin Analogs in the Management of Patients with Pulmonary Arterial Hypertension. Respiratory Medicine 2010;104:9-21. [CrossRef]

26. Coons JC, Clarke M, Wanek MR, Bauer A, Bream-Rouwenhorst HR. Safe and Effective use of Prostacyclins to Treat Pulmonary Arterial Hypertension. Am J Health-Syst Pharm 2013; 70:1716-23. [CrossRef]

27. Hall $\mathrm{H}$, Cote J, McBean A, Purden M. The Experiences of Patients with Pulmonary Arterial Hypertension Receiving Continuous Intravenous Infusion of Epoprostenol (Flolan) and Their Support Persons. Heart \& Lung 2012;41:35-43. [CrossRef]

28. McLaughlin VV, Palevsky HI. Parenteral and Inhaled Prostanoid Therapy in the Treatment of Pulmonary Arterial Hypertension. Clin Chest Med 2013;34:825-40. [CrossRef]

29. Gomberg-Maitland M. Olschewski H. Prostacyclin Therapies for the Treatment of Pulmonary Arterial Hypertension. Eur Respir J 2008;31:891-901. [CrossRef]

30. Muzevich KM, Chohan H, Grinnan DC. Management of Pulmonary Vasodilator Therapy in Patients with Pulmonary Arterial Hypertension During Critical IIllness. Critical Care 2014;18:523.

31. Kingman M. Archer-Chicko C, Bartlett M, Beckmann J, Hohsfield R, Lombardi S. Management of Prostacyclin Side Effects in Adult Patients with Pulmonary Arterial Hypertension. Pulmonary Circulation 2017;7:598-608. [CrossRef]

32. Doran AK, Ivy DD, Barst RJ, Hill N, Murali S, Benza RL. The Scientific Leadership Council of the Pulmonary Hypertension Association. Guidelines for the Prevention of Central Venous Catheter-Related Blood Stream Infections with Prostanoid Therapy for Pulmonary Arterial Hypertension. Int J Clin Pract Suppl 2008 160:5-9. [CrossRef]

33. O'Grady NP, Alexander M, Burns LA, et al. Guidelines for the Prevention of Intravascular Catheter-Related Infections. Clin Infect Dis 2011;52:1-32. [CrossRef]

34. Şanlı D, Sarikaya A. Santral Venöz Kateterde Kanıta Dayalı Hemşirelik Bakım Yönetimi. Yoğun Bakım Hemşireliği Dergisi 2016;20.

35. Gavin NC, Webster J, Chan RJ, Rickard CM. Frequency of Dressing Changes for Central Venous Access Devices on Catheter-Related Infections. Cochrane Database of Systematic Reviews 2016;2:CD009213. [CrossRef]

36. Bartlett M. Meeting the Challenge of Hospitalized PAH Patients Receiving IV Prostacyclins. Advances in Pulmonary Hypertension 2015;13:208-9.

37. Kingman M, Chin K. Safety Recommendations for Administering Intravenous Prostacyclins in the Hospital. Critical Care Nurse 2013;33:32-9. [CrossRef] 